\title{
Phylogenetic analysis of three genes of Penguinpox virus corresponding to Vaccinia virus G8R (VLTF-I), A3L (P4b) and H3L reveals that it is most closely related to Turkeypox virus, Ostrichpox virus and Pigeonpox virus
} Olivia Carulei ${ }^{1}$, Nicola Douglass ${ }^{1}$ and Anna-Lise Williamson*1,2

Address: ${ }^{1}$ Institute of Infectious Disease and Molecular Medicine and Department of Clinical Laboratory Sciences, Faculty of Health Sciences, University of Cape Town, Cape Town 7925, South Africa and ${ }^{2}$ National Health Laboratory Service, Groote Schuur Hospital, Observatory, Cape Town 7925, South Africa

Email: Olivia Carulei - Olivia.Carulei@uct.ac.za; Nicola Douglass - Niki.Douglass@uct.ac.za; Anna-Lise Williamson* - AnnaLise.Williamson@uct.ac.za

* Corresponding author

Published: 8 May 2009

Virology Journal 2009, 6:52 doi:10.1186/1743-422X-6-52

This article is available from: http://www.virologyj.com/content/6/1/52

(C) 2009 Carulei et al; licensee BioMed Central Ltd.

This is an Open Access article distributed under the terms of the Creative Commons Attribution License (http://creativecommons.org/licenses/by/2.0), which permits unrestricted use, distribution, and reproduction in any medium, provided the original work is properly cited.
Received: 3 February 2009

Accepted: 8 May 2009

\begin{abstract}
Phylogenetic analysis of three genes of Penguinpox virus, a novel Avipoxvirus isolated from African penguins, reveals its relationship to other poxviruses. The genes corresponding to Vaccinia virus G8R (VLTF-I), A3L (P4b) and H3L were sequenced and phylogenetic trees (Neighbour-Joining and UPGMA) constructed from MUSCLE nucleotide and amino acid alignments of the equivalent sequences from several different poxviruses. Based on this analysis, PEPV was confirmed to belong to the genus Avipoxvirus, specifically, clade $A$, subclade $A 2$ and to be most closely related to Turkeypox virus (TKPV), Ostrichpox virus (OSPV)and Pigeonpox virus (PGPV).
\end{abstract}

\section{Background}

Interest in the avipoxviruses, notably Fowlpox virus (FWPV) and Canarypox virus (CNPV) has increased due to their successful use as vaccines on commercial flocks and their extensive use and testing as vaccine vectors [1-8]. The genomes of both FWPV and CNPV have been sequenced and comparison reveals a high level of divergence with significant differences between orthologous ORFs and the terminal, variable genomic regions $[9,10]$. Analysis of the thymidine kinase gene showed only $64 \%$ amino acid identity between FWPV and CNPV compared to 97\% amino acid identity amongst the orthopoxviruses and $84 \%$ within the Leporipoxvirus genus [11]. This level of divergence is commonly seen between different Chordopoxvirus genera suggesting that the species within the Avipoxvirus genus are highly divergent. A novel avipoxvi- rus, Penguinpox virus (PEPV) was isolated from an African penguin (Spheniscus demersus) that was brought into the Southern African Foundation for the Conservation of Coastal Birds (SANCCOB) [12]. Lesions around the eyes, typical of avipoxvirus infection were noted and scrapings were taken. Virus was cultured from these scrapings and histological studies and restriction enzyme profile comparison to other known avipoxviruses, namely FWPV, CNPV, Turkeypox virus (TKPV) and Quailpox virus, confirmed that it was indeed a novel avipoxvirus [12]. Infectivity studies of different mammalian cell lines (CV-1, Vero, MDBK, RK-13, HeLa and HEF) and chick embryo fibroblasts (CEFs) showed that early stages of virus replication were supported, but no infectious progeny virus could be recovered [13]. It is currently unclear as to why PEPV cannot be successfully passaged in CEFs as CEFs 
have been shown to support replication of both FWPV and CNPV viruses. Also reported was the fact that PEPV transcriptases could recognize the Vaccinia virus (VACV) derived late promoter P11 linked to the $\beta$-galactosidase reporter gene, resulting in transient gene expression.

\section{Results and discussion}

One highly conserved gene, VLTF-1 (VACV G8R; fpv126 locus), was chosen for analysis in order to position PEPV in the larger chordopoxvirus group. Two additional genes, which are less highly conserved (P4b (VACV A3L; fpv167 locus) and the virion envelope protein p35 (VACV H3L; $f p v 140$ locus)) were selected for analysis in order to determine the relationship of PEPV to other avipoxviruses previously analysed at these loci [14]. The analysis involved MUSCLE [15] amino acid and nucleotide alignments and construction of UPGMA and Neighbour-Joining [16] phylogenetic trees based on these alignments.

The VLTF-1 gene encodes a late transcription factor, which is highly conserved amongst all poxviruses and is the most conserved protein between FWPV and CNPV with 95\% amino acid identity [10]. The nucleotide and amino acid sequences of 18 poxviruses representing all eight Chordopoxvirus genera were analysed at this locus. The overall tree topologies are as previously reported [17] and this analysis shows PEPV to belong to the Avipoxvirus genus, grouping with FWPV, in a separate clade from CNPV, with strong bootstrap support in both UPGMA and N-J trees (N-J tree shown below in Figure 1). PEPV showed 96\% amino acid identity to FWPV and 92\% identity to CNPV. The nucleotide identity was lower with $92 \%$ identity to FWPV and $84 \%$ identity to CNPV. Divergence is therefore more easily detected in the nucleotide sequences due to the increased number of changes and nucleotide sequences were therefore used for analysis of the P4b and envelope protein, p35 genes.

The P4b gene encodes a $75.2 \mathrm{kDa}$ virion core protein, which is highly conserved amongst all poxviruses [18] and this locus has been used previously in phylogenetic studies of avipoxviruses [14,19-21] to differentiate between major clades $\mathrm{A}, \mathrm{B}$ and $\mathrm{C}$ as well as minor clades A1, A2, A3, A4, B1 and B2. Figure 2 shows an N-J tree based on a MUSCLE nucleotide alignment of partial sequences (truncated to $450 \mathrm{nt}$ to ensure that all sequences were of equal length) of P4b orthologues from 37 avipoxvirus isolates from 17 different species of bird. This tree gives better resolution of the Avipoxvirus genus and shows PEPV to belong to the FWPV-like group of viruses (clade A) as opposed to the CNPV-like group of viruses (clade $\mathrm{B}$ ) or the Psittacine viruses (clade $\mathrm{C}$ ) in both N-J and UPGMA trees. FWPV and CNPV orthologues showed an average of $75 \%$ nucleotide identity to each other for the various isolates at this locus. PEPV showed

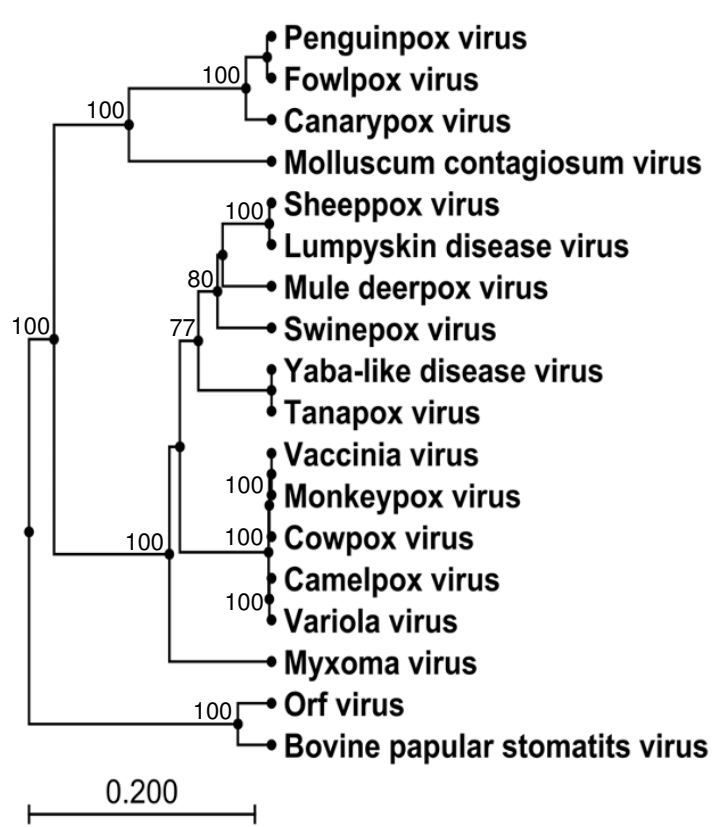

Figure I

Phylogenetic tree based on alignment of VLTF-I (VACV G8R; $f p v \mid 26$ locus) amino acid sequences. Neighbour-Joining phylogenetic tree constructed from the MUSCLE alignment of the amino acid sequences of the VLTFI gene (fpvl 26 locus) from 18 poxviruses. (Bootstrap values from 1000 replicate samplings are shown).

an average of $90 \%$ nucleotide identity to the various FWPV isolates and $74 \%$ identity to the various CNPV isolates. PEPV was found to belong to subclade A2 with $98 \%$ similarity to Falconpox virus (FLPV) and Albatrosspox virus (ABPV), and $100 \%$ homology to both the TKPV isolates (TKPV66 and TKPV98), the Ostrichpox virus (OSPV) isolate and two of the Pigeonpox virus (PGPV) isolates (PGPVTP2 and PGPVP).

Figure 3 shows an N-J tree based on the MUSCLE nucleotide alignment of orthologues of the envelope protein p35, which is an immunodominant antigen. PEPV was found to cluster with the TKPV isolates with strong bootstrap support while the pigeon isolate PGPVP clustered with the isolates from albatross and falcon in both N-J and UPGMA trees. PEPV was found to have $99 \%$ nucleotide identity with both TKPV isolates in subclade A2, compared to 95\% identity with ABPV and FLPV and 94\% with PGPVP.

Taken together these analyses confirm that PEPV belongs to the genus Avipoxvirus, and go on to show that PEPV 


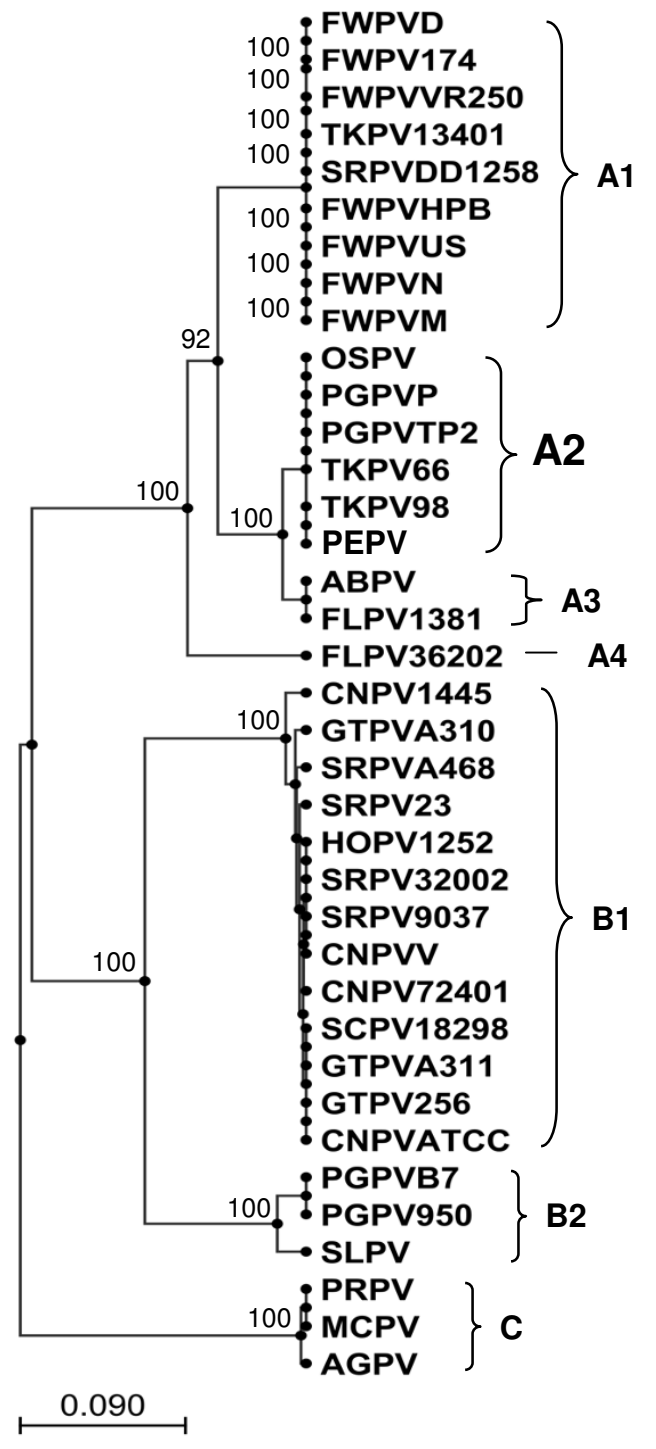

Figure 2

Phylogenetic tree based on alignment of P4b (VACV A3L; fpv 167 locus) DNA sequences. Neighbour-Joining phylogenetic tree constructed from the MUSCLE alignment of the nucleotide sequences of the P4b gene ( $\mathrm{fpvl} 67$ locus) of 37 Avipoxvirus isolates from 17 species of bird. (Bootstrap values from 1000 replicate samplings are shown). (ABPV = Albatrosspox virus; $A G P V=$ Agapornispox virus; $C N P V=$ Canarypox virus; FLPV = Falconpox virus; FWPV = Fowlpox virus; GTPV = Great titpox virus; HOPV = Houbara bustardpox virus; $M C P V=$ Macawpox virus; OSPV = Ostrichpox virus; $\mathrm{PEPV}=$ Penguinpox virus; $\mathrm{PGPV}=$ Pigeonpox virus; PRPV = Parrotpox virus; SCPV = Stone curlewpox virus; SLPV = Starlingpox virus; SRPV = Sparrowpox virus; TKPV = Turkeypox virus).

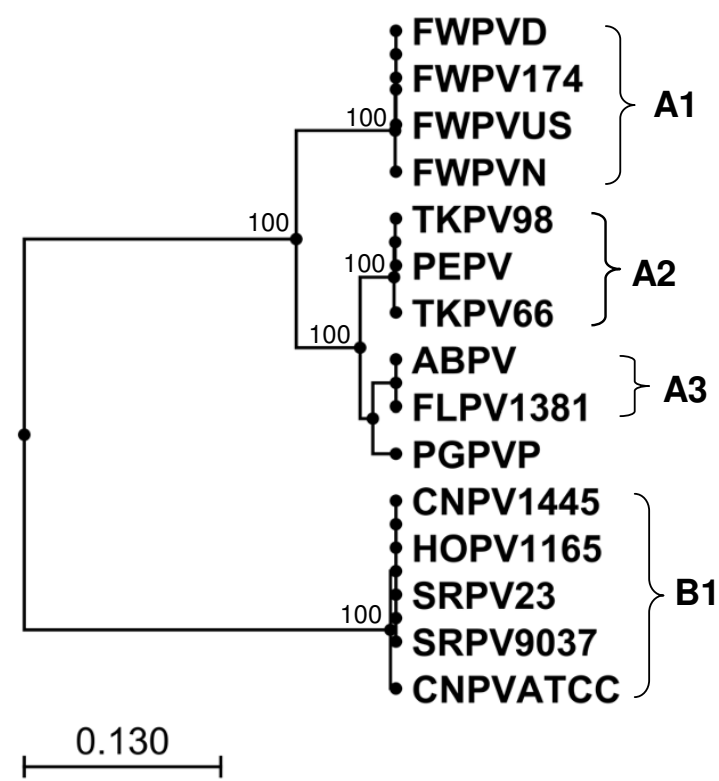

Figure 3

Phylogenetic tree based on alignment of H3L ( $f p v \mid 40$ locus) DNA sequences. Neighbour-Joining phylogenetic tree constructed from the MUSCLE alignment of the nucleotide sequences of the $\mathrm{H} 3 \mathrm{~L}$ gene ( $\mathrm{fpvl} 40$ locus) from I5 Avipoxvirus isolates from 9 species of bird. (Bootstrap values from 1000 replicate samplings are shown). (ABPV = Albatrosspox virus; CNPV = Canarypox virus; FLPV = Falconpox virus; FWPV = Fowlpox virus; $\mathrm{HOPV}=$ Houbara bustardpox virus; $\mathrm{PEPV}=$ Penguinpox virus; $\mathrm{PGPV}=$ Pigeonpox virus; $\mathrm{SRP}=$ Sparrowpox virus; TKPV = Turkeypox virus).

belongs to subclade A2 with the highest degree of similarity to TKPV isolates 98 and 66. Because there was no OSPV sequence available for the envelope protein p35 we can only speculate that PEPV and OSPV are highly similar based on the degree of similarity at the P4b gene. Previous work has shown that OSPV, TKPV and FWPV are genetically, antigenically and biologically related. Ostrich chicks housed in an enclosure that had previously housed pox infected turkeys became infected with a poxvirus and immunisation of susceptible chickens with this poxvirus protected them from FWPV challenge [22]. OSPV isolated from ostriches in Israel was found to produce productive infection in turkeys and furthermore, ostrich chicks in both Israel and South Africa could be protected by immunisation with FWPV vaccine $[23,24]$. The host range of TKPV has been reported to include both ostrich and Humboldt penguin (a close relative of the African penguin), 
Table I: Accession numbers of all loci used in this study

\begin{tabular}{|c|c|c|c|}
\hline Isolate & G8R (VLTF-I) & A3L (P4b) & H3L \\
\hline$A B P V$ & ---- & AM050392 & AM07I 388 \\
\hline AGPV & ----- & AY5303II & ----- \\
\hline BPSV & AY386265 & ----- & ----- \\
\hline CMPV & AF438I65 & ----- & ---- \\
\hline CNPVATCC & AY3I887I & AY3।887I & AY3I887I \\
\hline CNPV7240I & ---- & AY530306 & ----- \\
\hline CNPVI445 & ----- & AM050375 & AM07I5I2 \\
\hline CNPVV & ----- & AM050384 & ----- \\
\hline CPXV & AF482758 & ---- & ----- \\
\hline FLPV36202 & ----- & AY530306 & ----- \\
\hline FLPVI38I & ----- & AM050376 & AM07I5I5 \\
\hline FWPVVR250 & ---- & AY453172 & ---- \\
\hline FWPVUS & AFI98I00 & AFI98I00 & ----- \\
\hline FWPVHPB & ----- & AY530302 & ----- \\
\hline FWPVFP9 & ---- & AJ58I527 & AJ58I527 \\
\hline FWPVI74 & ----- & AM050377 & AM07I393 \\
\hline FWPVD & ---- & AM050380 & AM07I395 \\
\hline FWPVN & ----- & AM050379 & AM07I394 \\
\hline FWPVM & ----- & AM050378 & ----- \\
\hline GTPV256 & ---- & AY453175 & ----- \\
\hline GTPVA3।O & ----- & AY453173 & ----- \\
\hline GTPVA3।I & ---- & AY453174 & ----- \\
\hline HOPVI 252 & ---- & AM05038I & ----- \\
\hline HOPVII65 & ---- & ----- & AM07I5I3 \\
\hline LSDV & AF325528 & ----- & ---- \\
\hline MCPV & & AM050382 & ---- \\
\hline $\mathrm{MCV}$ & U60315 & ---- & ----- \\
\hline MDPV & AY689436 & ----- & ----- \\
\hline MPXV & AF380I38 & ----- & ----- \\
\hline MYXV & AFI70726 & ----- & ----- \\
\hline ORFV & AY386264 & ----- & ----- \\
\hline OSPV & ---- & AY530305 & ----- \\
\hline PEPV & FJ948I04 & FJ948I05 & FJ948I06 \\
\hline PGPVB7 & ---- & AY453I77 & ---- \\
\hline PGPVTP2 & ----- & AY530303 & ----- \\
\hline PGPVP & ----- & AM050385 & AM07I389 \\
\hline PGPV950 & ---- & AM050386 & ---- \\
\hline PRPV & ----- & AM050383 & ----- \\
\hline SCPVI8298 & ----- & AY530310 & ----- \\
\hline SLPV & ----- & AM05039I & ----- \\
\hline SPPX & AY077832 & & ----- \\
\hline SRPVDDI 258 & ---- & AY530307 & ---- \\
\hline SRPV32002 & ----- & AY530308 & ----- \\
\hline SRPVA468 & ----- & AY453I76 & ----- \\
\hline SRPV9037 & ----- & AM050389 & AM07I5II \\
\hline SRPV23 & ---- & AM050390 & AM07I5I0 \\
\hline SWPV & AF4I0I53 & ----- & ----- \\
\hline TANV & EF420I56 & ----- & ----- \\
\hline TKPVI340I & ---- & AY530304 & ----- \\
\hline TKPV66 & ---- & AM050387 & AM07I390 \\
\hline TKPV98 & ---- & AM050388 & AM07I39I \\
\hline VACV & AY243312 & ----- & ----- \\
\hline VARV & X69198 & ----- & ----- \\
\hline YLDV & AJ293568 & ----- & ----- \\
\hline
\end{tabular}

though this is unconfirmed [25]. Analysis of a PEPV IL-10 like protein (data not shown) shows this protein to be most closely related to turkey (Meleagris gallopavo) and chicken (Gallus gallus) IL-10, with $27 \%$ amino acid identity followed by the IL-10 like protein found in CNPV with $26 \%$ amino acid identity. The CNPV IL-10-like protein showed only $20 \%$ identity to the proteins from chicken and turkey. PEPV infection is evident in juvenile African penguins especially in the summer months when the penguins spend the majority of their time on land (moulting and/or nesting) and there are large numbers of mosquitoes present, which act as mechanical vectors to transmit virus (personal communication Dr. Nola Parsons, SANC$\mathrm{COB})$. Further research is underway to determine whether outbreaks in different avian species are caused by the same virus or by different but closely related viral species.

\section{Materials and methods}

PEPV was grown on the chorioallantoic membranes of embryonated hens' eggs as described previously [13] to produce a viral stock from which DNA was extracted. Viral DNA was extracted by conventional methods as described previously [12] with the following modifications to the lysis buffer: $10 \%$ N-lauryl sarcosinate, $50 \mathrm{mM}$ Tris pH7.8, $200 \mathrm{mM} \beta$-mercaptoethanol and no SDS. The PEPV genomic DNA was sequenced using the Roche/454 GSFLX system and all bioinformatics analysis was performed using the CLC Bio Main Workbench.

Accession numbers of all loci used in this study (Table 1).

For further information on sequences used in this analysis please refer to [14].

\section{Competing interests}

The authors declare that they have no competing interests.

\section{Authors' contributions}

OC carried out the molecular genetic, sequence alignment and phylogenetic studies and drafted the manuscript. ND and ALW participated in the design of the study, analyses and interpretation of data and revision of the manuscript. All authors read and approved the final manuscript.

\section{Acknowledgements}

This work is based upon research supported by the South African Research Chairs Initiative of the Department of Science and Technology and National Research Foundation.

\section{References}

I. Anderson RJ, Hannan CM, Gilbert SC, Laidlaw SM, Sheu EG, Korten S, Sinden R, Butcher GA, Skinner MA, Hill AVS: Enhanced CD8+T cell immune responses and protection elicited against plasmodium berghei malaria by prime boost immunization reg- 
imens using a novel attenuated fowlpox virus. J Immunol 2004, 172:3094-3100.

2. Dale C], De Rose R, Stratov I, Chea S, Monteflori DC, Thompson S, Ramshaw IA, Coupar BEH, Boyle DB, Law M, Kent SI: Efficacy of DNA and Fowlpox virus priming/boosting vaccines for Simian/human immunodeficiency virus. Virology 2004, 78:138|9-13828.

3. El Garch H, Minke JM, Rehder J, Richard S, Edlund Toulemonde C, Dinic S, Andreoni C, Audonnet JC, Nordgren R, Juillard V: A west Nile virus (WNV) recombinant canarypox virus vaccine elicits WNV-specific neutralizing antibodies and cell-mediated immune responses in the horse. Vet Immunol Immunopath 2008, 1 23:230-239.

4. Engelmeyer J, Larsson M, Lee A, Lee M, Cox WI, Steinman RM, Bhardwaj $N$ : Mature dendritic cells infected with canarypox virus elicit strong anti-human immunodeficiency virus CD8+ and CD4+ T-cell responses from chronically infected individuals. J Virol 200I, 75:2|42-2I53.

5. Jäger E, Karbach J, Gnatic S, Neumann A, Bender A, Valmori D, Ayyoub M, Ritter E, Ritter D, Jäger D, Panicali D, Hoffman E, Pan L, Oettgen $\mathrm{H}$, Old LJ, Knuth $\mathrm{A}$ : Recombinant vaccinia/fowlpox NYESO-I vaccines induce both humoral and cellular NY-ESOI-specific immune responses in cancer patients. Proc Natl Acad Sci 2006, 103:14453-14458.

6. Karaca K, Swayne DE, Grosenbaugh D, Bublot M, Robles A, Spackman E, Nordgren R: Immunogenicity of fowlpox virus expressing the avian influenza virus $\mathrm{H} 5$ gene (TROVAC AIV-H5) in cats. Clin Diagn Lab Immunol 2005, I 2: I 340-1342.

7. Poulet H, Brunet S, Boularand C, Guiot AL, Leroy V, Minke J, Audonnet JC, Desmettre P, Tartaglia J: Efficacy of a canarypox virusvectored vaccine against feline leukaemia. Vet Rec 2003, | 53:|4|-| 45.

8. Taylor J, Meignier B, Tartaglia J, Languet B, Guillemin F, Desmettre P, Paoletti E: Biological and immunogenic properties of a canarypox-rabies recombinant, ALVAC-RG (vCP65) in non-avian species. Vaccine 1995, 13:539-549.

9. Afonso CL, Tulman ER, Lu Z, Zsak L, Kutish GF, Rock DL: The genome of fowlpox virus. J Virol 2000, 74:38I5-383I.

10. Tulman ER, Afonso CL, Lu Z, Zsak L, Kutish GF, Rock DL: The genome of canarypox virus. J Virol 2003, 78:353-366.

II. Amano H, Morikawa S, Shimizu H, Shoji I, Kurosawa D, Matsuura Y, Miyamura T, Ueda $Y$ : Identification of the Canarypox virus thymidine kinase gene and insertion of foreign genes. Virology 1999, 256:280-290.

12. Kow D: Characterization of Avipoxviruses for use in recombinant vaccines. In PhD thesis University of Cape Town, Department of Clinical and Laboratory Sciences; 1992.

13. Stannard L, Marais D, Kow D, Dumbell KR: Evidence for incomplete replication of a penguin poxvirus in cells of mammalian origin. J Gen Virol 1998, 79:1637-1646.

14. Jarmin S, Manvell R, Gough RE, Laidlaw SM, Skinner MA: Avipoxvirus phylogenetics: identification of a PCR length polymorphism that discriminates between the two major clades. I Gen Virol 2006, 87:2191-2201.

15. Edgar RC: MUSCLE: multiple sequence alignment with high accuracy and high throughput. Nucleic Acids Res 2004, 32:1792-1797.

16. Saitou $N$, Nei M: The neighbour-joining method: a new method for reconstructing phylogenetic trees. Mol Biol Evol 1987, 4:406-425.

17. Gubser $C$, Hue S, Kellam P, Smith GL: Poxvirus genomes: a phylogenetic analysis. J Gen Virol 2004, 85: 105-II7.

18. Binns MM, Boursnell MEG, Tomley FM, Campbell j: Analysis of the Fowlpox virus gene encoding the $4 \mathrm{~b}$ core polypeptide and demonstration that it possesses efficient promoter sequences. J Virol 1989, 170:288-291.

19. Luschow D, Hoffman T, Hafez HM: Differentiation of avian poxvirus strains on the basis of nucleotide sequences of $4 b$ gene fragment. Avian Dis 2004, 48:453-462.

20. Tadese T, Reed WM: Use of restriction fragment length polymorphism, immunoblotting, and polymerase chain reaction in the differentiation of avian poxviruses. I Vet Diagn Invest 2003, I 5: $|4|-\mid 50$

21. Weli SC, Traavik T, Tryland M, Coucheron DH, Nilssen Ø: Analysis and comparison of the $4 \mathrm{~b}$ core protein gene of avipoxviruses from wild birds: evidence for interspecies spatial phylogenetic variation. Arch Virol 2004, I49:2035-2046.

22. Shivaprasad HL, Kim TJ, Woolcock PR, Tripathy DN: Genetic and antigenic characterization of a poxvirus isolate from ostriches. Avian Dis 200I, 46:429-436.

23. Allwright DM, Burger WP, Geyer A, Wessles J: Avian pox in ostriches. J S Afr Vet Assoc 1994, 65:23-25.

24. Perelman B, Gur-lavie A, Samberg Y: Pox in ostriches. Avian Path 1998, 17:735-739.

25. Gerlach H: Viruses. In Avian medicine: principles and application Abridged edition Edited by: Ritchie BW, Harrison GJ, Harrison LR. Lake Worth, Florida: Wingers Publishing; 1997:87I.
Publish with Biomed Central and every scientist can read your work free of charge

"BioMed Central will be the most significant development for disseminating the results of biomedical research in our lifetime. "

Sir Paul Nurse, Cancer Research UK

Your research papers will be:

- available free of charge to the entire biomedical community

- peer reviewed and published immediately upon acceptance

- cited in PubMed and archived on PubMed Central

- yours - you keep the copyright 